\title{
Chronic Hepatitis C Virus (HCV)-associated Cryoglobulinemia and its possible impact on the skin in Egyptian Patients
}

\section{Amin Mohamed Abd El Baki ${ }^{1}$, Mohamed A.Ezzel Arab²Nabil Abd El Mageed}

${ }^{I}$ Tropical Medicine Department, National Hepatology and Tropical Medicine Research Institute.

${ }^{2}$ Internal Medicine Department, National Hepatology and Tropical Medicine Research Institute

${ }^{3}$ Dermatology Department,National Hepatology and Tropical Medicine Research Institute.

\begin{abstract}
Background:

Chronic hepatitis $\mathrm{C}$ virus (HCV) infection may have extremely variable clinical consequences and is more than just a liver disease; it has been associated with numerous extra-hepatic manifestations (EHM). According to various international studies Mixed Cryoglobulinemia (MC) was found to be the most common EHM, however its local prevalence in Egyptian HCV patients was not clearly studied. The aim of our study was to investigate the frequency of cryoglobulinaemia in sera of chronic HCV patients and their association with clinical symptoms especially, vasculitis.
\end{abstract}

\section{Method:}

One hundred patients with chronic HCV infection attending the outpatient clinic of the National Hepatology and Tropical Medicine Research Institute were interviewed. Patients with decompensated liver disease, on interferon therapy, having end-stage renal disease or coexisting viral infection like hepatitis B surface antigen positive patients were all excluded from the research. All patients were subjected to general and dermatological examination for liver affection signs; cryoglobulinemia related clinical manifestations and/or associated dermatoses. Cryoglobulins, CBC, LFT. AFP, ALP, KFT, ANA and RF were assessed.

\section{Results:}

Overall $15 \%$ of 100 patients were positive for presence of cryoglobulins in their sera. We found a relatively high incidence of clinical symptoms commonly accompanying cryoglobulinemic cases in the form of Purpura, Arthralgia, Generalized weakness, Peripheral Neuropathy and Reynaud's phenomenon with prevalence of $26.67 \%, 46.67 \%, 53.33 \%, 40 \%$ and $6.67 \%$ respectively. Our data also demonstrated that $46.67 \%$ (7) of our 15 cryopositive patients had concomitant skin manifestations in the form of Pruritus $40 \%$ (6) and Vasculitis $26.67 \%$ (4) $(\mathrm{P}=0.004)$ which was significant in comparison with prevalence of vasculitis in all patients $4.7 \%$ (4 patients). Generalized weakness and fatigue, which is the most prevalent symptoms related to Chronic Hepatitis $\mathrm{C}$ (CHC) patients whether positive or negative for cryoglobulinemia, were present in $52 \%$ of all patients. Other associated dermatological diseases in all patients were Lichen Planus, Psoraiasis, Urticaria, Necrolytic Acral Erythema (NAE) and Vitiligo with prevalence of $(1 \%),(1 \%),(5 \%),(1 \%)$ and $(2 \%)$ respectively. The most common dermatological disease was pruritus $36 \%$ (36) of all patients and $40 \%$ (6) in cryopositive patients. Regarding liver condition there was no significant correlation between presence of cryoglobulins and biochemical parameters. However, we found a significant correlation between presence of cryoglobulinemia and presence of ANA in sera of HCV patients with incidence of 40\%) in 
comparison to $4.7 \%$ in cryonegative patients respectively while there is no significant correlation as regard RF (40\% in cryopositive $\$ 55.3 \%$ in cryonegative patients). Among all patients $10 \%$ (10) were ANA positive and 53\% (53) were RF positive. We also found that $26.67 \%$ (4) of our cryopositive patients were associated with vasculitic skin lesions. For each patient a skin biopsy was taken from the lesional area and tissue (Insitu) PCR was done to detect the presence of HCV RNA within it. Biopsy results revealed that 3 biopsies were positive and 1 biopsy was negative for HCV RNA by tissue PCR.

\section{Conclusion:}

The prevalence of cryoglobulinaemia in Egypt may be lower than other areas. In HCV patient complaining from generalized weakness, arthralgia, purpuric skin lesions, peripheral neuropathy, Reynaud's phenomenon or renal troubles, serum cryoglobulins presence should be searched for.

\section{Introduction}

Chronic hepatitis $\mathrm{C}$ virus (HCV) infection affects more than 170 million persons worldwide and responsible for the development of liver cirrhosis in many cases (Wohnsland et al., 2007).

$\mathrm{HCV}$ infection is considered the most common etiology of chronic liver disease in Egypt, where prevalence of antibodies to $\mathrm{HCV}$ (anti-HCV) is approximately 10-fold greater than in the United States and Europe (Strickland et al., 2002). The prevalence among the general Egyptian population is approximately 13\% (Frank et al., 2000; Habib et al., 2000).

Chronic HCV infection has been associated with numerous extrahepatic manifestations; these manifestations can involve multiple organ system, including renal, dermatologic, hematologic and rheumatologic systems (Gumber et al., 1995; El-serag et al., 2002)

The most common EHM is Mixed Cryoglobulinemia, cryoglobulins are found in $50 \%$ of chronic HCV infection patients. Cryoglobulins are found to be 11 times more frequent in a veterans $\mathrm{HCV}$ cohort group than their respective control population (El-serag et al., 2002).

Cryoglobulins are immunoglobulins that precipitate at a temperature below $37^{\circ} \mathrm{C}$. Mixed cryoglobulinemia is a chronic immune complex-mediated disease strongly associated with hepatitis $\mathrm{C}$ virus (HCV) infection. It is a vasculitis of small and medium-sized arteries and veins, due to the deposition of complexes of antigen, cryoglobulin and complement in the vessel walls.

The main clinical features of mixed cryoglobulinemia vasculitis include the triad of palpable purpura, arthralgias, and weakness, and other pathological conditions such as glomerulonephritis, peripheral neuropathy, skin ulcers, and widespread vasculitis(Iannuzzella et al., 2010). Although circulating cryoglobulins are not always related to the presence of symptomatology, nearly half of the patients with cryoglobulinemia present clinical manifestations (Ferri et al., 2002).

Severe symptoms from cryoglobulinemia appear to respond to interferon treatment, but relapse occurs frequently once treatment is discontinued (Lunel et al., 1999).

\section{Aim of The Work}

Purpose of the study is to assess the presence of cryoglobulinemic immunoglobulins in serum of chronic HCV patients and its possible impact on the skin as a manifested Cryoglobulinemic Vasculitis.

\section{Patients and Methods}

The study included one hundred Egyptian persons, had chronic hepatitis C 
virus (HCV) infection [proved by +ve anti$\mathrm{HCV}$ antibodies and +ve HCV RNA by Quantitative Polymerase Chain Reaction (PCR) tests], were collected from the outpatient clinic at The National Hepatology and Tropical Medicine Research Institute (NHTMRI). Patients with decompensated liver disease, on interferon therapy, having end-stage renal disease or coexisting viral infection like hepatitis B surface antigen positive or HIV patients, patients with either hematological disorder, cancer and autoimmune systemic diseases such as rheumatoid arthritis (RA) and systemic lupus erythematosus (SLE), were all excluded from the study .

All patients were subjected to the following standard protocol:

Full medical history, Full clinical examination and Laboratory investigations including: CBC, Liver function tests, Renal function tests, Plasma alpha fetoprotein (AFP), Serum ANA and RF, HBsAg, $\mathrm{HBcAb}$ and Anti HIV antibodies (ELISA), Anti HCV antibodies (ELISA), Quantitative HCV RNA by real time PCR test (for HCV +ve ELISA), Qualitative Cryoglobulin precipitation test, abdominal Ultrasonography (U/S), and

Skin biopsies: From patients with vasculitis (one biopsy from area just near the vasculitic lesions and the second one is from non-lesional areas in the same anatomic site), for detection of HCV-RNA by Polymerase chain reaction (HCV-RNA PCR) insitu.

\section{Statistical analysis:}

The clinical and laboratory data were recorded on an investigative report form. These data were analyzed using the mean, standard error, student t-test and chi-square by SPSS 13.

\section{Results}

The results are shown in tables 1-4
The data of this study demonstrated presence of cryoglobulins in 15/100 patients with an incidence of $15 \%$ of all patients (Figure 1).

In this study the 15 cryopositive patients were found to have a relatively high incidence of clinical symptoms which are commonly accompanying cryoglobulinemic cases in the form of Purpura, Arthralgia, Generalized weakness, Peripheral Neuropathy and Reynaud's phenomenon with prevalence of $26.7 \%, 46.66 \%$, $53.33 \%, 40 \%$ and $6.67 \%$ respectively (Table no.1). It was also demonstrated that $46.67 \%(7 / 15)$ of the cryopositive patients had concomitant skin manifestations in the form of pruritus $40 \%(6 / 15)$ and vasculitis $26.67 \%$ (4/15). None of the cryopositive patients had NAE (Table no.2).

Other associated dermatological diseases in all patients were Lichen Planus, Psoraiasis, Urticaria, Necrolytic Acral Erythema (NAE) and Vitiligo with prevalence of $(1 \%),(1 \%),(5 \%),(1 \%)$ and (2\%) respectively. The most common dermatological disease was pruritus in 36 $(36 \%)$ of all patients and in $6(40 \%)$ of cryopositive patients (Table no.2). However, regarding ANA and RF there was a significant correlation between presence of cryoglobulinemia and presence of ANA in sera of $\mathrm{HCV}$ patients (with incidence of $40 \%$ ) in comparison to $4.7 \%$ in cryonegative patients while it is insignificant as regard the presence of RF $(40 \%$ in cryopositive $\$ 55.3 \%$ in cryonegative patients) (Table no.1).

HCV RNA was detected in skin biopsy of $3 / 4 \quad(75 \%)$ of patients with cryopositive purpuric cutaneous lesions clinically diagnosed as vasculitis. However, HCV RNA was not detected in normal skin of same patients (Table no.3). High viral load was detected in 11/15 (73.33\%) of the cryopositive patients and in only $29 / 85$ $(34.12 \%)$ of the cryonegative patients (Table no.4). 
Figure (1): Shows the incidence of cryoglobulinemia in the patients of the study:

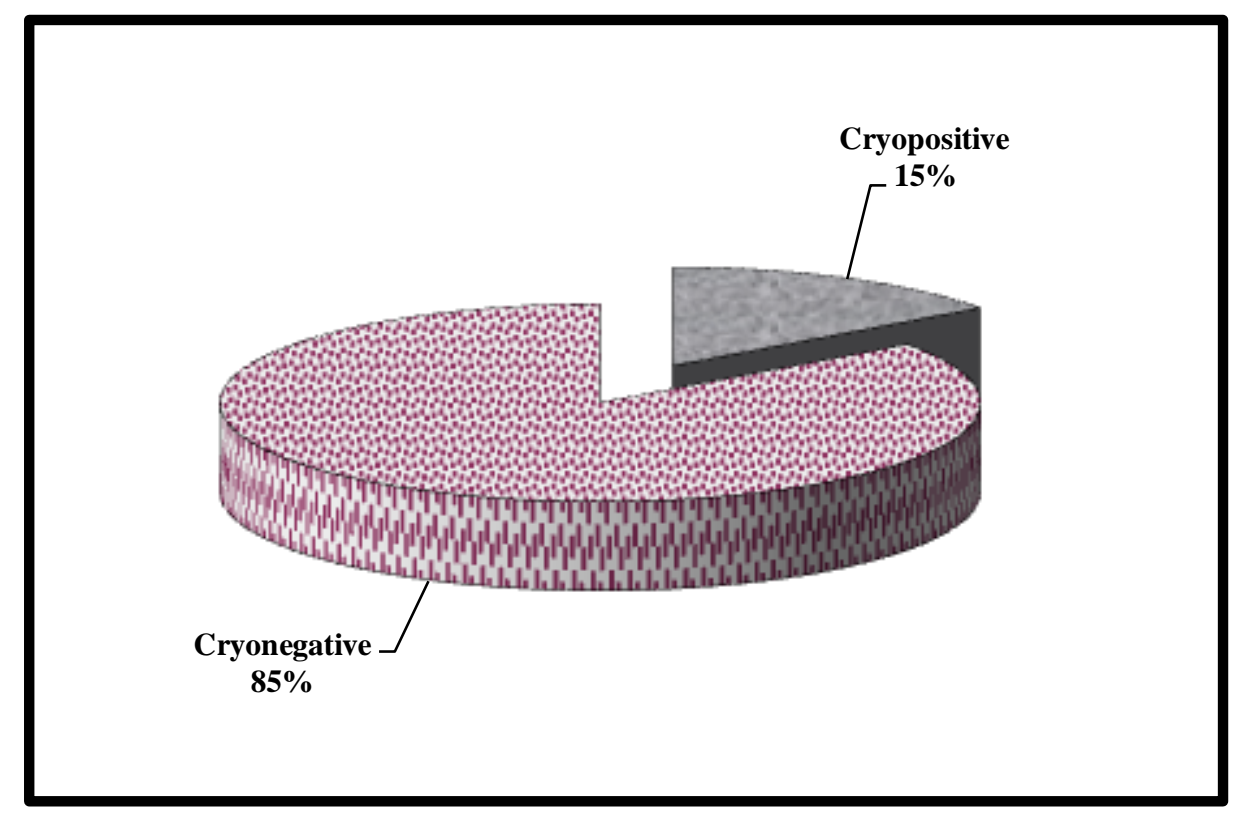

Table (1): Shows the distribution of important clinical findings , ANA and RF in cryo+ve patients in comparison with cryo-ve patients:

\begin{tabular}{|c|c|c|c|c|}
\hline \multirow{3}{*}{$\begin{array}{c}\text { Related clinical } \\
\text { manifestations + } \\
\text { ANA and RF }\end{array}$} & \multicolumn{2}{|c|}{ Cryoglobulins } & \multirow{2}{*}{\multicolumn{2}{|c|}{ Chi-square }} \\
\hline & \multirow{2}{*}{$\begin{array}{c}\text { Cryo +ve } \\
\text { (\% from all } \\
\text { cryo+ve) }\end{array}$} & \multirow{2}{*}{$\begin{array}{c}\text { Cryo -ve } \\
\text { (\% from all } \\
\text { cryo-ve) }\end{array}$} & & \\
\hline & & & $\mathbf{X}^{2}$ & P-value \\
\hline Arthralgia & $7(46.67 \%)$ & $34(40 \%)$ & 0.234 & 0.628 \\
\hline Purpura & $4(26.67 \%)$ & $4(4.7 \%)$ & 8.355 & $0.004 *$ (significant) \\
\hline $\begin{array}{l}\text { Peripheral } \\
\text { neuropathy }\end{array}$ & $6(40 \%)$ & $17(20 \%)$ & 2.880 & 0.090 \\
\hline Generalized weakness & $8(53.33 \%)$ & $44(51.76 \%)$ & 0.013 & 0.911 \\
\hline $\begin{array}{c}\text { Reynaud's } \\
\text { phenomenon }\end{array}$ & $1(6.67 \%)$ & $2(2.3 \%)$ & 0.815 & 0.367 \\
\hline ANA & $6(40 \%)$ & $4(4.7 \%)$ & 17.65 & $0.000 *$ (significant) \\
\hline RF & $6(40 \%)$ & $47(55.29 \%)$ & 1.197 & 0.274 \\
\hline
\end{tabular}

*significant at P-value $<0.05$ 
Table (2): Shows prevalence of dermatological diseases among Cryo+ve patients in comparison with cryo-ve patients:

\begin{tabular}{|c|c|c|c|c||}
\hline \multirow{2}{*}{ Other skin disease } & \multicolumn{2}{|c||}{ Cryoglobulins } & \multicolumn{2}{c|}{ Chi-square } \\
\cline { 2 - 3 } \cline { 5 - 6 } & $\begin{array}{c}\text { Cryo +ve } \\
\text { \% from all } \\
\text { cryo+ve) }\end{array}$ & $\begin{array}{c}\text { Cryo -ve } \\
\text { from all cryo- } \\
\text { ve })\end{array}$ & $\mathbf{X}^{2}$ & P-value \\
\hline \hline Pruritus & $6(40 \%)$ & $30(35.29 \%)$ & 0.003 & 0.953 \\
\hline Lichen planus & 0 & $1(1.17 \%)$ & 0.970 & 0.3246 \\
\hline Psoriasis & 0 & $1(1.17 \%)$ & 0.970 & 0.3246 \\
\hline $\begin{array}{c}\text { Necrolytic Acral } \\
\text { Erythema }\end{array}$ & 0 & $1(1.17 \%)$ & 0.970 & 0.3246 \\
\hline Vitiligo & 0 & $2(2.35 \%)$ & 0.160 & 0.689 \\
\hline Urticaria & 0 & $5(5.88 \%)$ & 0.103 & 0.7480 \\
\hline Vasculitis & $4(26.67 \%)$ & $4(4.71 \%)$ & 5.637 & $\begin{array}{c}0.017 * \\
(\text { significant })\end{array}$ \\
\hline
\end{tabular}

*significant at $P$-value $<0.05$

Table (3): Shows the presence of HCV-RNA Insitu in the biopsies of vasculitic skin lesions among cryo+ve patients:

\begin{tabular}{|c|c|}
\hline Skin biopsy & Cryo +ve \\
\hline Vasculitis & $4(100 \%)$ \\
\hline $\begin{array}{c}\text { HCV-RNA-PCR Insitu } \\
\text { (+ve) }\end{array}$ & $3(75 \%)$ \\
\hline
\end{tabular}


Table (4): Shows the presence of high viremia among cryo+ve patients in comparison with cryo-ve patients:

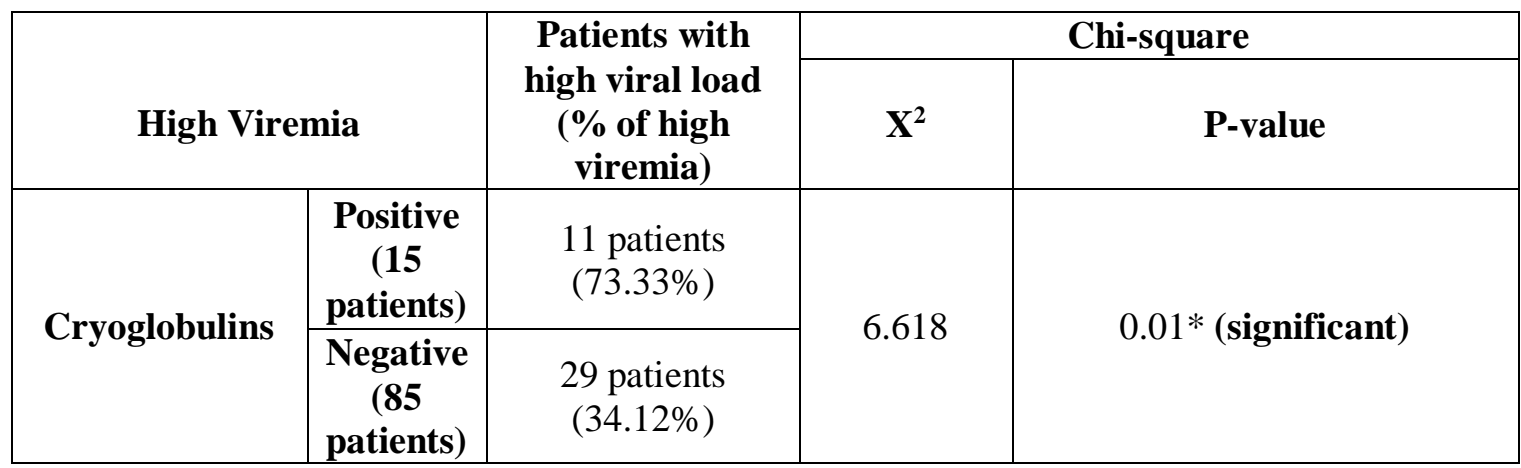

*significant at P-value $<0.05$

\section{Discussion}

Chronic hepatitis $\mathrm{C}$ virus (HCV) is emerging as a serious worldwide problem, being the second most common chronic viral infection in the world with a global prevalence of about 3\% (about 180 million people)(Craxo et al., 2008). Egypt has the highest prevalence of HCV infection in the world, $8-30 \%$ of the general population varying according to age group and according to whether in urban or rural areas; this is ten times greater than any other country in the world (Strickland, 2006, El-Hawary et al., 2007 and Marzouk et al., 2007). HCV infection may have extremely variable clinical consequences and is more than just a liver disease, it has been associated with numerous extra hepatic manifestations (EHM), and these manifestations can involve multiple organ system, including renal, dermatologic, hematologic and rheumatologic system (Galossi et al., 2007). Mixed Type II cryoglobulinaemia is the major extrahepatic manifestation of HCV infection( Owlia 2007).it is a systemic vasculitis which manifests clinically by a classical triad of purpura, weakness and arthralgias(Ferri 2008). The term cryoglobulinemia refers to the presence of single or mixed immunoglobulins (Igs) in the serum, these (Igs) precipitate at a temperatures below $37^{\circ} \mathrm{C}$ and redissolve on rewarming. This is an in vitro phenomenon which can be observed in a wide spectrum of hematologic, infectious and immunorheumatologic disorders (Sansonno et al., 2005).

It has been established that low levels of circulating mixed cryoglobulins can be detected in over $50 \%$ of HCVinfected individuals (Sansonno et al., 2003) and were found to be 11 times more frequent in a group of HCV patients than their respective control population in a study by El-serag et al (2002). In the present study the results regarding the prevalence of cryoglobulinemia in $\mathrm{HCV}$ patients were $15 \%$ versus $4 \%$ in controls. This is in agreement with previous studies that recorded higher prevalence of circulating mixed cryoglobulins in $\mathrm{HCV}$ patients compared to their respective control population.

Detecting cryoglobulinemia in a percentage of $15 \%$ matches results of $\mathbf{G a d}$ et al., (2003) who reported that the prevalence of cryoglobulinemia in Egyptian HCV patients was $14 \%$, and of Weiner et al., (1998) who detected cryoglobulins in $19 \%$ of their HCV patients. On the other hand a recent Egyptian study done by Meky et al., (2007) reported that prevalence of cryoglobulins in sera of chronic $\mathrm{HCV}$ patients was only $8.78 \%$. The prevalence of HCV-related cryoglobulinemia varies greatly from one study to another with a prevalence of serum cryoglobulins ranging from $19 \%$ to $>50 \%$ (Della Rossa et al., 
2001 ; Ferri et al., 2004 ; Tedeschi et al., 2007 and Fallahi et al., 2008), a finding that raises questions about the factors underlying its occurrence. This discrepancy in results may be due to different cryoglobulins detection methods from a study to another, but this cannot be the only reason for such different results. The involvement of particular $\mathrm{HCV}$ genotypes, environmental and/or host genetic factors should contribute to the pathogenesis of MC (Ferri, 2008). In this study the relatively hot climate in Egypt may play an important role in the results discrepancy between this study and the other European studies, in addition to prevalent HCV genotype 4 here in Egypt (90\%), which is different from that prevalent in most Western countries, (Vinod, 2004 and El-Hawary et al., 2007). Another suggested cause is that patients of this study were not having HBV or HIV infections plus being relatively newly diagnosed cases.

Other environmental factors may play a role and genetic factors of different populations such as HLA typing may also be involved in the pathogenesis of cryoglobulinemia (Ferri et al., 2002; Liakana et al., 2002).

Mixed cryoglobulinemia can be detected in up to half of patients with HCV infection, but in $90 \%$ of cases it causes no symptoms and requires no specific treatment (Ali and Zein, 2005). Another study by Tedeschi et al., (2007) reported that $20-56 \%$ of patients with HCV had cryoglobulinemia and only $10-27 \%$ of them, showed clinical signs consistent with the syndrome of cryoglobulinemia.

The data in this study regarding age, sex or biochemical parameters were of no significant correlation; these results were in general agreement with data reported by Liakana et al., (2002). Regarding ANA and RF, our results (10\% were ANA positive and 53\% were RF positive) were in general agreement with Meky et al., (2007) as they found that $9.1 \%$ of their patients were ANA positive and that $58.94 \%$ of their patients were RF positive.
In this study regarding incidence of clinical symptoms which are commonly accompanying cryoglobulinemic cases, generalized weakness and fatigue were present in $52 \%$ of all patients and in 8/15 (53.33\%) of cryoglobulin +ve cases and so, it is considered the most prevalent symptoms and this was in general agreement with that of Mohammed et al.,(2010), Meky et al., (2007), and Stefanova-Petrova et al., (2007) as they reported that fatigue and weakness were the most prevalent symptoms related to Chronic Hepatitis C (CHC) patients.

Regarding extra hepatic manifestations (EHM) The findings in this study showed that $62 \%$ of the patients had one or more EHM, this was in general agreement with that of Cacoub et al., (2000) who reported that $40-74 \%$ of patients infected with HCV develop at least one EHM during the course of the disease, and also Stefanova-Petrova et al., (2007) reported that $(76 \%)$ of the patients had at least one extra hepatic manifestation. the most common extra hepatic manifestations in this study were rheumatologic (19\%) and cutaneous $(17 \%)$.

Different studies report different frequencies of various dermatoses with chronic HCV infection patients. Azafar et al., (2008) noticed skin manifestations in $54 \%$ of their patients and generalized pruritus was the most common finding seen in $15.9 \%$ patients, Dervis and Serez, (2005) revealed pruritus to be most frequent symptom seen in $18.57 \%$ of patients. Other dermatoses included leukocytoclastic vasculitis and lichen planus seen in $4.28 \%$ each. In this study we detected other associated dermatological diseases in the patients as follows, Lichen Planus, Psoraiasis, Urticaria, Necrolytic Acral Erythema (NAE) and Vitiligo with prevalence of $(1 \%),(1 \%),(5 \%),(1 \%)$ and (2\%) respectively. The most common dermatological symptom was pruritus in 36 $(36 \%)$ of all patients and in $6(40 \%)$ of cryopositive patients. 
Circulating mixed cryoglobulins (MCs) were detected in 40-60\% of $\mathrm{HCV}$ infected patients whereas overt cryoglobulinaemic vasculitis developed in only 5-10\% of the cases (Saadoun et al., 2007), the results of the present study showed that vasculitis incidence among all patients was $4 \%$. In this study HCV RNA was detected in biopsies of the vasculitic skin lesions, by insitu hybridization in $3 / 4$ (75\%) of the cases, this finding could be explained by what was mentioned by Ferri et al (2003) about the hypothesis of a direct involvement of $\mathrm{HCV}$ in the immunecomplex-mediated vasculitic lesions, as well as in the underlying lymphoproliferative disorder.

\section{Conclusion:}

We conclude that CHCV infection is an important risk factor for cryoglobulinaemia. Serum cryoglobulins presence should be searched for when mixed cryoglobulinemia is suspected in $\mathrm{HCV}$ patient complaining from generalized weakness, arthralgia, purpuric skin lesions, peripheral neuropathy, Reynaud's phenomenon or renal troubles. The prevalence of cryoglobulinaemia in Egypt may be lower than other areas. The involvement of particular $\mathrm{HCV}$ genotypes(genotype 4 about 90\%), environmental and/or host genetic factors should contribute to the pathogenesis of MC. Furthermore, a negative cryoglobulin test result does not exclude mixed cryoglobulinemia, as the test can be falsely negative.

\section{References}

- Wohnsland, A., Hofmann, WP. and Sarrazin, C. (2007): Viral determinants of resistance to treatment in patients with hepatitis C. Clin Microbiol Rev. Jan 27; 20(1):23-38. 982.

- Strickland, GT., El-hefni, H. and Salman, T. (2002): Role of hepatitis C infection in chronic liver disease in Egypt. Am J Trop Med Hyg. 67(4):436-42.

- Frank, C., M. K. Mohamed, G. T. Strickland, D. Lavanchy, R. R. Arthur, L.
S. (2000): The role of parenteral antischistosomal therapy in the spread of hepatitis $\mathrm{C}$ virus in Egypt. Lancet. 355:887.

- Habib, M., Mohamed, MK. and Abdel-

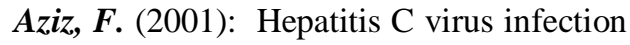
in a community in the Nile Delta: risk factors for seropositivity. J Hepatol. 33(1)248-53.

- Gumber, SC. and Chopra, S. (1995): Hepatitis C: a multifaceted disease. Review of extra hepatic manifestations. Ann Intern Med. 123:615-620.

- El-Serag, HB., Hampel, H. and Yeh, C. (2002): Extra hepatic manifestations of hepatitis among United States male veterians. J Hepatol. 36:1439-45.

- Iannuzzella F, Vaglio A, Garini G.(2010): Management of hepatitis $C$ virus-related mixed cryoglobulinemia. Am J Med. May;123(5):400-8.

- Ferri, C., Zignego, A.L. and Pileri, S.A. (2002): Cryoglobulins (review). J Clin Pathol. 55:4-13.

- Lunel, F. and Cacoub, P. (1999): Treatment of autoimmune and extra hepatic manifestations of hepatitis $\mathrm{C}$ virus infection. J Hepatol. 31(Suppl 1):210-6.

- Craxo A,Laffi G and Zignego AI.(2008): Hepatitis C virus (HCV) infection: a systemic disease. Mol. Aspects Med.,29(12):85-95.

- Strickland, GT. (2006): Liver Disease in Egypt: Hepatitis C Superseded Schistosomiasis as a Result of Iatrogenic and Biological Factors. Hepatology, Vol. 43, No. 5, 915-922.

- El-Hawary, MA., El-Raziky, MS., Esmat, G., Soliman, H. and Abouzied, A. (2007): Assessment of hepatic fibrosis in pediatric cases with hepatitis $\mathrm{C}$ virus in Egypt. World J Gastroenterol. 13(20):2846-51.

- Marzouk, D., Sass, J., Bakr, I., El Hosseiny, M., Abdel-Hamid, M. and Rekacewicz, C. (2007): Metabolic and cardiovascular risk profiles and hepatitis $\mathrm{C}$ virus infection in rural Egypt. Gut. 56:1105-1110.

- Galossi, A., Guarisc, R., Bellis, L. and Puoti, C. (2007): Extra hepatic Manifestations of Chronic HCV Infection. J Gastrointestin Liver Dis. Vol.16 No 1, 6573.

- Owlia MB, Sami R, Akhondi M, Salimzadeh A (2007): Cryoglobulinaemia in hepatitis C-positive patients in Iran. Singapore Med J. Dec;48(12):1136-9 
- $\quad$ Ferri C(2008). Mixed cryoglobulinemia. Orphanet J Rare Dis. Sep 16;3:25.

- Sansonno, D. and Dammacco, F. (2005): Hepatitis $C$ virus. Cryoglobulinemia. And vasculitis: immune complex relations. Lancet Infect Dis; 5:227-236

- Sansonno, D., De Re, V., Lauletta, G., Tucci, FA. and Dammacco, F. (2003): Monoclonal antibody treatment of mixed cryoglobulinemia resistant to interferon alpha with an anti-CD20. Blood. 101(10):3818-26.

- Gad, A., Tanaka, E., Matsumoto, A., ElHamid Serwah, A., Ali, K. and El-Gohary, A. (2003): Factors predisposing to the occurrence of cryoglobulinemia in two cohorts of Egyptian and Japanese patients with chronic hepatitis $\mathrm{C}$ infection: ethnic and genotypic influence. J Med Virol. 70:594-599.

- Weiner, SM., Berg, T. and Berthold, $H$. (1998): A clinical and virological study of hepatitis $\mathrm{C}$ virus-related cryoglobulinemia in Germany. J Hepatol. 29:375-84.

- Meky, FA., Abdel-Mageed, N., AbdelHamid, M., El-Kafrawy, SH., El-Kassas, M. and Esmat, G. (2007): Extraheptic Dermatologic Manifestations in Chronic Hepatitis C: An Egyptian Study. Med. J. Cairo Univ., Vol.75, No.3 Suppl. September: 93-98.

- Della Rossa, A., Tavoni, A., Baldini, C. and Bombardieri, S. (2001): $\quad$ Mixed Cryoglobulinemia and Hepatitis C Virus Association. IMAG. 2001 June; 3:430-434.

- Ferri, C., Sebastiani, M., Giuggioli, D., Cazzato, M. and Longombardo, G. (2004): Mixed cryoglobulinemia: demographic, clinical, and serological features, and survival in 231 patients. Sem Arthritis Rheum. 33:355-74.

- Tedeschi, A., Baratè, C., Minola, E. and Morra, E. (2007): Cryoglobulinemia. Blood Reviews. 21, 183-200.

- Fallahi, P., Ferri, C., Ferrari, SM., Pampana, A., Sanaonno, D. and Antonelli A. (2008): The Emerging Extrahepatic Manifestations of Hepatitis C Virus Infection in Chronic Hepatitis and Mixed Cryoglobulinemia. Hepatitis Monthly. 8(3): 207-211.
- Vinod, KD. (2004): Hepatitis C. Rev Gastroenterol Disord. 4 Suppl. 1:S31-8.

- Liakana, V., Speiciene, D. and Irnius, A. (2002): Prevalence of cryoglobulinemia in patients with chronic HCV infection. Med Sci Monit. 8(1):CR31-6.

- Ali, A. and Zein, N. (2005): Hepatitis C Infection: A systemic disease with extra hepatic manifestations. Cleveland Clinic Journal of Medicine. 72:1005-19.

- Mohammed RH, Elmakhzangy HI, Gamal A, Mekky F, El Kassas M, Mohammed N, Hamid MA, Esmat G.(2010): Prevalence of rheumatologic manifestations of chronic hepatitis $\mathrm{C}$ virus infection among Egyptians. Clin Rheumatol. Apr 22. [Epub ahead of print]

- Stefanova-Petrova, DV., Tzvetanska, AH., Naumova, EJ., Mihailova, AP. and Hadjiev, EA. (2007): Chronic hepatitis C virus infection: Prevalence of extra hepatic manifestations and association with cryoglobulinemia in Bulgarian patients. World J Gastroentrol. 13(48):6518-28.

- Cacoub, P., Renou, C. and Rosenthal, E. (2000): Extrahepatic manifestations associated with hepatitis $\mathrm{C}$ virus infection. A prospective multicenter study of 321 patients. Medicine. 79:47-56.

- Azafar, NA., Zaman, T., Rashid, T. and Jahangir, M. (2008): Cutaneous manifestations in patients of hepatitis C. J Pak Assoc Dermatol. 18:138-43.

- Dervis, E. and Serez, K. (2005): The prevalence of dermatologic manifestations related to chronic hepatitis $\mathrm{C}$ virus infection in a study from a single center in Turkey. Acta Dermatoven APA. 14(3):93-8.

- Saadoun, D., Landau, DA., Calabrese, LH. and Cacoub, PP. (2007): Hepatitis Cassociated mixed cryoglobulinemia: a crossroad between autoimmunity and lymphoproliferation. Rheumatology. 46(8):1234-42.

- Ferri, C., Giuggioli, D., Cazzato, M., Sebastiani, M., Mascia, MT. and Zignego AL. (2003): HCV-related cryoglobulinemic vasculitis: An update on its etiopathogenesis and therapeutic strategies. Clin Exp Rheumatol. 21(Suppl. 31):S78S84. 


\title{
إرتباط الألتهاب الكبدى المزمن سى بالجلوبيولينات البردية وتأثيرها على الجلد فى المرضى المصرين بالجلوبنين المبرين
}

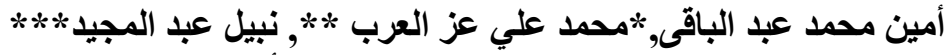

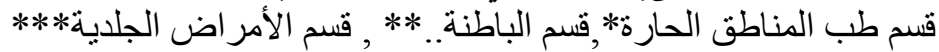 \\ المعهة القومى للأمر اض المنوطنة و الكبد_الهيئة العامة للمعاهد و المستشفيات التعلية التيمية
}

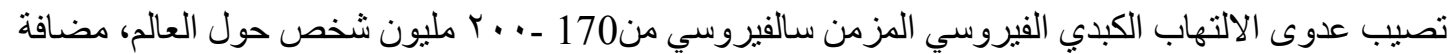

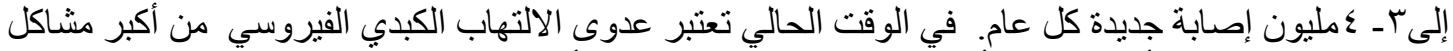
الصحة العالمية وسبب أساسي هام لأمر اض الكي الكبد المزمنة في جميع أنحاء العالم.

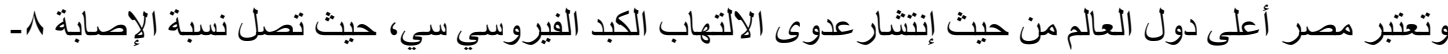

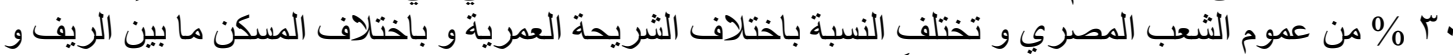

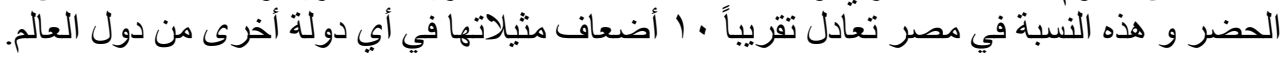

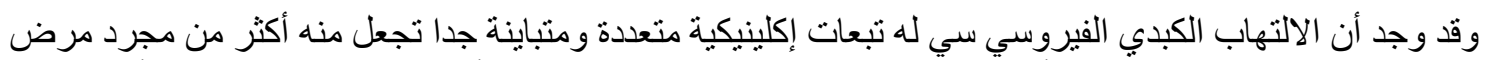

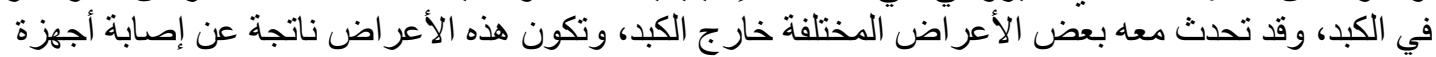

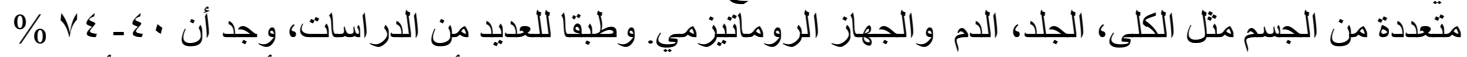

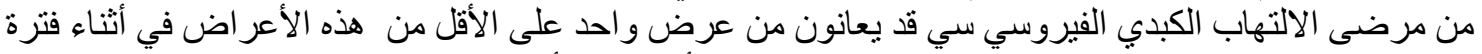

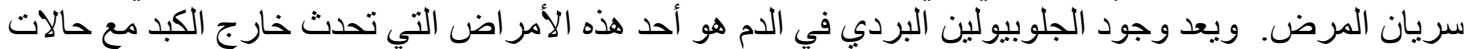

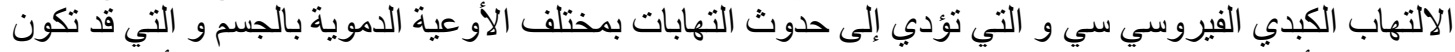
مصحوبة بأعر اضي في صورة شعور بالإر هاق، طفح جلدي، آلام بالمفاصل، ظاهرة رينو، الإئه التهاب الأوعية الدموية، أمر اض الكلى أو أمر اض في الأعصاب الطرفية.

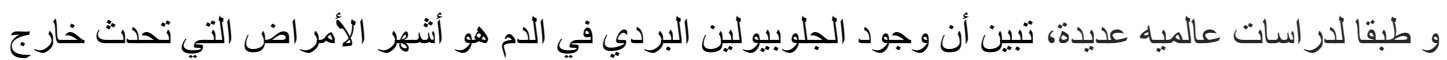

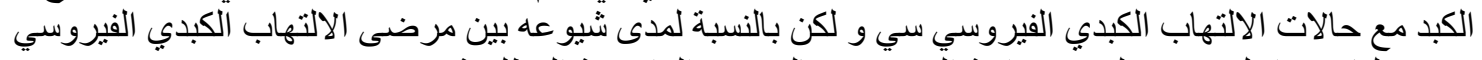

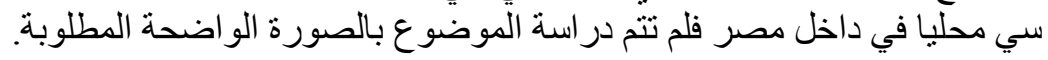

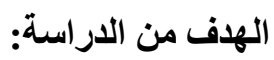

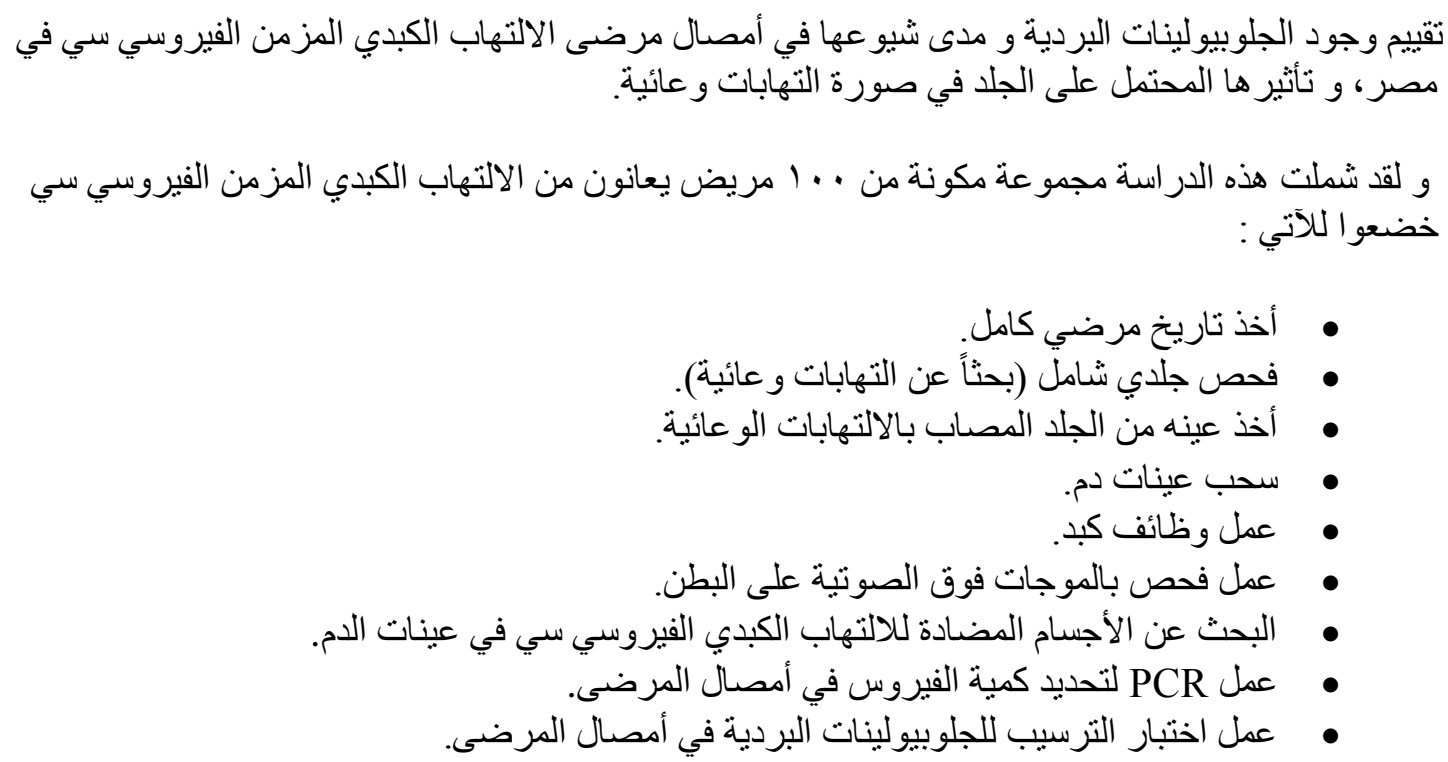




$$
\text { • عمل التحليل الإحصائي للنتائج. }
$$

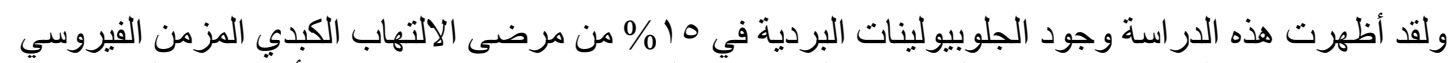

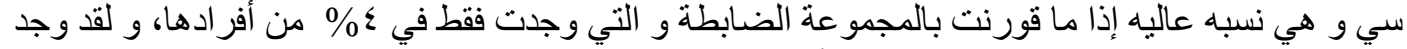

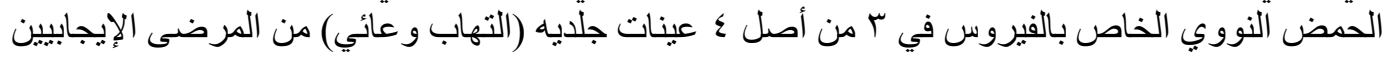
للجلوبيولينات البردية.

\section{و لقد أوصت هذه الدراسة بالأتي:}

• عمل اختبار ات معملية للبحث عن الجلوبيولينات البردية في مرضى الالتهاب الكبدي الفيروسي سي.

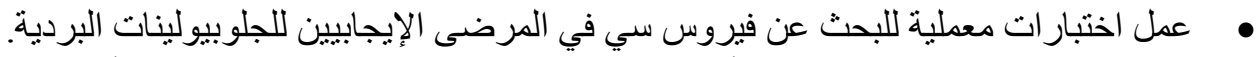

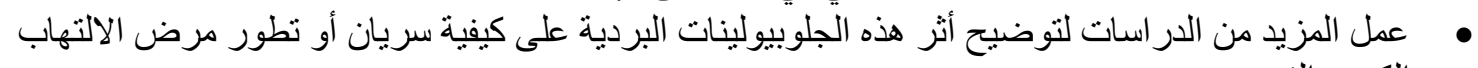
الكبدي الفيروسي سي. 